\title{
Impact analysis of smartphone use and Youth Family Development (BKR) program on family disharmony in Magetan Regency
}

\section{Puji Nurhayati ${ }^{*}$, Pratama Dharmika Nugraha ${ }^{2}$, Heidy Paramitha Devi ${ }^{3}$, Andri Wahyu Utomo ${ }^{4}$}

${ }^{183}$ Faculty of Economics and Business, Universitas PGRI Madiun, Indonesia

${ }^{2 \& 4}$ Faculty of Health and Sciences, Universitas PGRI Madiun, Indonesia

${ }^{*}$ Corresponding author

E-mail address: pujinurhayati@unipma.ac.id

DOI: https://doi.org/10.21107/sml.v3i1.7038

\begin{tabular}{|c|c|}
\hline Article Info & Abstract \\
\hline $\begin{array}{l}\text { Keywords: } \\
\text { Smartphone use } \\
\text { Youth } \\
\text { BKR program } \\
\text { Family disharmony }\end{array}$ & $\begin{array}{l}\text { This article examines the impact of the use of smart phone and BKR programs } \\
\text { on family disharmony. Smartphone are devices that have both positif and } \\
\text { negative effects. Indonesia is predicted to get a demographic bonus in 2020- } \\
2030 \text { with the highest number of teenagers, and the majority of smartphone } \\
\text { users are teenagers. BKR is a program that serves to help parenting to avoid } \\
\text { deviant behavior. This research uses quantitative methods, with primary } \\
\text { data of } 300 \text { respondents. The sample of this study consisted of } 150 \text { PKK } \\
\text { groups and } 150 \text { teenagers. Data collection technique is using questionnaire } \\
\text { data. Data analysis technique is using path analysis and SPSS } 21.0 \text { software } \\
\text { The results of the study stated that the use of smartphone had a negative } \\
\text { and not significant effect on family disharmony, smartphone usage had a } \\
\text { negative and significant effect on BKR program and smartphone usage had } \\
\text { a negative and significant effect on family disharmony. The use of a smart } \\
\text { phone does not have an impact on family disharmony because of effective } \\
\text { communication between family members. The existence of the BKR program } \\
\text { is still needed to assist families in fostering their teenagers so that it is wiser } \\
\text { to use a smartphone. }\end{array}$ \\
\hline
\end{tabular}

Citation suggestion:

Nurhayati, P., Nugraha, P.D., Devi, H.P., \& Utomo, A. W. (2020). Impact analysis of smartphone use and Youth Family Development (BKR) program on family disharmony in Magetan Regency. Simulacra, 3(1), 95-107. https:// doi.org/10.21107/sml.v3i1.7038

Received 7 April 2020; Received in revised form 28 May 2020; Accepted 2 June 2020; Published online 25 June 2020. 


\section{Introduction}

One tangible form of Industrial Revolution 4.0 technology is the use of smartphones. The number of internet users using smartphones in Indonesia in 2019 is projected to be 175 million or around $65.3 \%$ of Indonesia's 268 million populations. The projected figure increased 32 million or $22.37 \%$ compared to the last survey of the Indonesian Internet Service Providers Association (APJII) in 2017, which amounted to 143 million (Beritasatu.com, 2019). Internet users in 2019 are expected to increase to 178.4 million (CAGR 12\%). Meanwhile, mobile internet users are predicted to be 89.4 million (CAGR $9.23 \%$ ) with $90 \%$ of the smartphone market in Indonesia dominated by Android and $75 \%$ in the world (Permana, 2019).

The use of increasingly popular smartphones indeed cannot be separated from the positive and negative impacts for its users, especially for adolescents. The negative impacts that occur from the use of smartphones include deviant sexual behaviour, cases of HIV/AIDS and drugs (Narcotics, Alcohol, Psychotropic, and other addictive substances). Such cases can occur because of the use of deviant smartphones, such as watching porn videos, viewing videos that are full of violence, and activities related to other promiscuity.

The 2015 inter-census population survey results also showed that the population aged 15-24 years reached 42,061.2 million or $16.5 \%$ of the total population of Indonesia. The number of adolescents in Indonesia is 64 million, or around $27.6 \%$ of the total population (Kusumaryani, 2017). A large number of adolescents and their problems makes this issue important and requires great attention in their formation. This is evident from the fact that unhealthy sexual behavior among adolescents, especially unmarried adolescents, tends to increase. The Indonesian Child Protection Commission
(KPAI) notes that there are 5.9 million drug addicts out of 87 million children (0-18 years). In addition, KPAI also revealed that there were 2,218 cases related to health problems and drugs that affected children. There are $15.69 \%$ of cases of child drug addicts and $8.1 \%$ of cases of child drug dealers (Okezone. com, March 6, 2018). The existence of these cases can mean that adolescents are very vulnerable to the three risks experienced by adolescents due to deviant behavior (KRR Triads) (sexuality, drugs, HIV/AIDS).

Basic Health Research in 2013 proved that pregnancy at age $<15$ years mainly occurred in rural areas $0.03 \%$ where teenage pregnancy in rural areas $(2.71 \%)$ was higher than in urban areas $(1.28 \%)$. On the other hand, support for abortion practices also increased in 2012 compared to 2007. Permana (2011) revealed that $12.5 \%$ of adolescents who did not have an understanding of reproductive health agreed to an abortion. Meanwhile, the proportion of adolescents who have an understanding of reproductive health and agree to practice abortion tends to be smaller, at $9 \%$. The inferential analysis shows that adolescents who have an understanding of reproductive health are permissive to abortion 0.8 times lower than adolescents who do not have an understanding of reproductive health.

Two researches by Strickler (2002) dan Permana (2011) revealed that several factors influence the adolescent mindset that caused them to be permissive to fertility regulation, increasing women's participation in the labor market will be hindered if unwanted pregnancy occurs due to increased sexual activity, gender equality as if giving the right for women to decide whether or not to continue a pregnancy, and socioeconomic factors that trigger changes in adolescent mindset.

Meanwhile, the prevalence of drug use in Indonesia at the level of high school students is relatively not much different compared 
to tertiary institutions. Adolescents who have used drugs are relatively similar $(4.3 \%)$ between high school and university. However, in 2016, adolescents who used drugs at the high school level reached 2.4\%, and universities reached $1.8 \%$. This means that adolescent drug users at the high school level are higher than at the university level.

The development of HIV/AIDS cases in Indonesia is still a problem and has instead shown an increase from year to year. The highest number of people living with HIV/ AIDS is in the provinces of Papua, East Java and DKI Jakarta. The cumulative number of people living with AIDS from 1987 - December 2016 was 86,780 people. The highest cumulative percentage of AIDS is in adolescents aged 20-29 years at $31.4 \%$ and adolescents aged $15-19$ years at 2.7\% (Direktorat Jendral Pencegahan dan Pengendalian Penyakit, 2018).

Cases of juvenile delinquency that occur as a result of promiscuity such as premarital sex and drug use, among others, are caused by the use of smartphones in the wrong way. The use of smartphones for adolescents has positive and negative impacts in terms of social, physical or health, and spiritual. The role of parents is crucial in this case. For this reason, guidance is needed in the form of the Youth Family Development (BKR) program.

The Youth Family Development program is a government program implemented by the National Population and Family Planning Agency (BKKBN). This program is regulated in the 2012 BKR Management Handbook. The BKR program aims to increase the knowledge of parents and adolescents and raise awareness and responsibility of children and adolescents to improve family resilience through healthy and harmonious communication interactions in a happy and lively household life atmosphere prosperous. BKR consists of two aspects, namely effective communication and the role of parents. Communication and family roles are vital and are needed to reduce family disharmony. Parents have a massive role in increasing children's confidence to solve problems. Parents or families also play a role as the primary and first teacher and school for children. Therefore, parents or families must know adolescent problems.

A study proves the impact of smartphone usage on social interaction in adolescents. Research shows that the use of smartphones caused dependence and results in reduced social interaction, especially in the family sphere (Muflih et al., 2017). Adolescents have a higher tendency to communicate with anyone through smartphone technology devices (Resti, 2015). Other studies state the same thing. The use of technology in the form of smartphones is felt like a faster and more effective method to bridge communication between parents and children (Odendaal et al., 2006). The study also mentioned that the use of technology did not harm the communication of parents and adolescents without connecting other factors.

The positive impact of the use of smartphones for adolescents, namely: a) facilitate access to information widely and quickly, b) facilitate communication, mainly if used as a discussion forum, c) increase student knowledge because it facilitates information search. The negative impacts of using smartphones for adolescents include: a) making users lazier because they only rely on smartphones, b) weakening the user's brain because it makes it easy to find information and makes teens lazy to think, c) disrupts the health of their users, primarily related to eye health, d) make users addicted to social media, games and other applications, e) jeopardize financial arrangements because the use of smartphones that cannot be separated from the internet caused the excessive use of credit, f) allows teens to access things that should not be accessed such as videos pornographic. 
However, other studies suggest that smartphone usage, busy schedules, and activities make sharing information difficult (Sharen Gifary dan Iis Kurnia N., 2014). The use of a smartphone can have a positive effect, which facilitates communication even at long distances. The negative effect is making adolescents experience dysfunction and the time of face-to-face interaction with others decreases (Widiastuti \& Elshap, 2015). Therefore, it can be concluded that there is a relationship between the role of family and children's behavior in avoiding the harmful effects of using gadgets. Other research also stated that communication between parents and adolescents is more done through faceto-face compared to using a smartphone even though face-to-face communication is more ideal (Widiartanto, 2016). To achieve family harmony, careful preparation is needed from each family through the inculcation of moral values by carrying out eight family functions (BKKBN, 2014: 1) Religious Function. Religion is a basic need for every human being in the womb. The family is the first place a child knows religion. Families instill, grow, and develop religious values so that children have good character and are devoted to God Almighty. The function of religion has 12 fundamental values, namely faith, piety, honesty, tolerance which is characterized by awareness, diligence, piety, obedience, love to help, discipline, courtesy, patience and sincerity and compassion; 2) Socio-Cultural Function. Humans are social creatures. Not only does it require help from others, but humans also require interaction with fellow human beings. Every family has its own culture according to their place of residence. The existence of these differences is expected to be able to maintain, preserve, and develop local socio-cultural wealth.

There are seven fundamental values that must be instilled in the family from the socio-cultural aspect. The fundamental values consist of cooperation, courtesy, harmony, caring, togetherness, tolerance and nationality. The function of love and affection, parents must fulfill love and affection. Meanwhile, children's rights are to get love and affection. Fulfillment of children's rights to love and affection can make children love others and learn to respect others. The eight fundamental values that must be understood and instilled in the family are empathy, intimate, fair, forgiving, faithful, helpful, sacrifice and responsibility. Protection function, the family has a function as a shelter for family members. Families must provide a sense of security, calm and peace for their family members. Five fundamental values that must be understood and instilled in the family are safe, forgiving, responsive, steadfast and caring.

Reproductive function is related to reproductive knowledge to get offspring from a legitimate married couple. Reproductive knowledge is essential for adolescents because of the low knowledge of adolescents about reproductive health, including around the fertile period. The low knowledge of adolescents has the potential to increase sexually transmitted diseases (STIs). Three fundamental values that must be understood in the function of reproduction are responsibility, soundness, and determination. The function of socialization and education, the family functions as an educator, guide, and companion in the development of the child physically, mentally, socially and spiritually so that the child can socialize with others.

Seven basic values must be understood and instilled in the family, namely selfconfidence, flexible, proud, diligent, creative, responsibility, and cooperation. Economic function, economics is a social science that studies various behaviors of economic actors toward economic decisions made. In the family, the economy is associated with the 
process of demand and fulfillment of the economic needs of the family to meet primary, secondary and tertiary needs. Adolescents who want and have planned to have a family must have a picture of family finances to be managed. The steps that must be taken to prepare a financial plan before the family are to analyze income and expenses, discuss with potential partners about financial goals in 3 stages (short term ( $<1$ year), mediumterm (1-5 years) and long term ( $>5$ years)), prepare to fund to achieve all dreams, plan business opportunities when savings are sufficient, manage finances with discipline; 8) Environmental functions. Efforts to develop environmental functions are one way for families to actualize themselves and build themselves into a prosperous family by being facilitated by community institutions as their social environment and facilitating support from the government. Two basic values must be understood and instilled in the family, namely, clean and disciplined.

Based on the background of the problems that have been described above, due to the increasing level of deviation of adolescent behavior that impacts on health, drug use and others in the Industrial Revolution 4.0 era, the researchers want to examine the impact arising from technological developments in the form of smartphone usage on family disharmony and the role and the importance of the Youth Family Development program in the community.

Because Indonesia is predicted to get a demographic bonus in 2020-2030, the action is needed to reduce the level of deviation of adolescent behavior through the role of parents in a family. If adolescents are now qualified as human resources, then the demographic bonus in 2020-2030 can be enjoyed. Conversely, if adolescents are currently a resource that is not qualified, then the demographic bonus will not be thoroughly enjoyed. The novelty of this study is to include indicators of the role of parents in the BKR component and identify eight family functions in the family disharmony component.

\section{Method}

\section{Research Object}

The object of this study consisted of six villages in Magetan Regency, which were in the lowlands and highlands. The villages that were the object of research included Gonggang Village, Pacalan Village, Turi Village, Sobontoro Village, Candirejo Village and Tawanganom Village. The object of research was taken in different plains because there are differences in the distance of access to go to places of entertainment with modern styles such as malls, cafes, and cinemas. These facilities were considered to influence social and lifestyle patterns. People in the highlands had limited access compared to people in the lowlands.

\section{Population and Sample}

This research was descriptive. The study population was the Family Welfare Development (PKK) and Adolescent Groups in East Java. The sample in this study was PKK and adolescents in Magetan Regency, East Java Province, totaling 300 people. The sampling technique in the study was purposive sampling. The criteria for the sample of this study were PKK members who had children aged 10-24 years and adolescents aged 10-24 years.

\section{Data Collection Technique}

The data used in this study were primary. Primary data was collected through the distribution of surveys in the form of questionnaires to respondents (PKK and Adolescents group in Magetan Regency) 
to obtain information about the impact of smartphone use and the Youth Family Development Program (BKR). A scale of 1 to 5 is used to measure each statement in the questionnaire. The attitude support of the respondents was connected with the words: Strongly Disagree (1), Disagree (2), Neutral (3), Agree (4), Strongly Agree (5).

\section{The Technique of Data Analysis}

Before the data is further analyzed, testing of research instruments was needed. The tests were testing the validity and reliability of the research instrument. Hypothesis testing in this study used SPSS 21.0 software which was carried out using the Classical Assumption Test (Normality Test, Multicollinearity Test, Autocorrelation Test and Heteroscedasticity Test) and Path Analysis followed by Sobel Test.

\section{Results and Discussion}

\section{Pilot Test}

Based on the determining something through the law of closeness, similarity, tendency or circumstances that are most close to reality (rule of thumb), the results of a pilot test showed that the validity and reliability tests were met. All indicators of smartphone usage variables, 73 youth family development programs (BKR) and Disharmony were declared valid. The pilot test can be described as follows: 1) indicators on smartphone usage variables with parent respondents were valid. The reliability test results showed that the responses from respondents from time to time and in the same conditions were consistent or reliable with a Cronbach's Alpha value of 0.964 ; 2) indicators on the variable of family disharmony with the respondent's parents were declared valid. The reliability test results showed that the responses of respondents from time to time and in the same conditions were consistent or reliable with a Cronbach's Alpha value of $0.990 ; 3$ ) indicators on the variables of an adolescent family building with parents' respondents were declared valid.

The reliability test results showed that the responses of respondents from time to time and in the same conditions were consistent or reliable with a Cronbach's Alpha value of $0.972 ; 4$ ) indicators on the variables of smartphone usage with teen respondents were valid. The reliability test results showed that the responses of respondents from time to time and in the same conditions were consistent or reliable with a Cronbach's Alpha value of 0.969 ; 5) indicators on the variable of family harmony with adolescent respondents were declared valid. The reliability test results showed that the responses from respondents from time to time and in the same conditions were consistent or reliable with a Cronbach's Alpha value of 0.973 ; 6) indicators on the variables of adolescent family development with adolescent respondents were declared valid. The reliability test results showed that the responses of respondents from time to time and in the same conditions were consistent or reliable with a Cronbach's Alpha value of 0.930 .

\section{Classic Assumption Test}

Based on the tendency or circumstances that were close to reality (rule of thumb), the results of the classic assumption test which includes normality test, multicollinearity test, autocorrelation test and heteroscedasticity test were met. This could be interpreted that this research could proceed to the hypothesis test: 


\section{Lowland areas}

The test was carried out using nonparametric statistics from the KolmogorovSmirnov (K-S) test. If the significance value is $>0.05$, it was assumed the normality of the data was met. The results of tests carried out produced a demographic significance level at lowlands of 0.095. So, it could be said that data in the lowlands were normally distributed. The results of testing the assumption of autocorrelation in the lowlands by the Durbin Watson method in the table showed a DW value of 1.705 , which indicated that the data in the lowlands was autocorrelation free.

The calculation results in the above table showed the tolerance value of the lowlands approaching number 1 and the VIF value around number 1 and not exceeding number 10. Therefore, it could be concluded that the independent variables used in this regression model were free from multicollinearity or could be trusted and objective. Scatterplot images showed that the points spread randomly and do not form specific patterns; this showed that there was no indication of heteroscedasticity in the model.

\section{Highland areas}

The test used non-parametric statistics from the Kolmogorov-Smirnov (K-S) test, if the significance value was $>0.05$ then it was assumed that the normality of the data was met. The results of tests carried out obtained significance level in the highlands demographic data of 0.200 . Because the significance value of the plateau data was $0.200>0.05$, it could be said that the data was normally distributed.

The results of testing the assumption of autocorrelation with the Durbin Watson method in the table showed a DW value of 1.579 which indicates that the plateau data was free of autocorrelation. The results of the multicollinearity test calculation showed the value of tolerance data in the highlands approached number 1 and the VIF value around number 1 and did not exceed number 10. Therefore, it was concluded that the independent variables used in this regression model were free of multicollinearity or could be trusted and objective. Scatterplot images showed that the points spread randomly and do not form certain patterns. This showed that there was no indication of heteroscedasticity in the model.

\section{Highland and lowland area data in Magetan Regency}

The test used non-parametric statistics from the Kolmogorov-Smirnov (K-S) test; if the significance value was $>0.05$, then it was assumed that the normality of the data was met. The results of tests carried out obtained the level of significance of data at low and high plains of 0.098. Because the significance value of $0.098>0.05$, it could be said that the lowland and highland data were normally distributed. The results of testing the assumption of autocorrelation by the Durbin Watson method in the table showed a DW value of 1.579 which indicates that the data was low and high was free of autocorrelation. The results of calculations on the multicollinearity test showed the tolerance value of the lowland and high data close to number 1 and the VIF value around number 1 and did not exceed number 10. Therefore, it was concluded that the independent variables used in this regression model were free from multicollinearity or could be trusted and objective. Scatterplot images showed that the points spread randomly and do not form certain patterns. This showed that there was no indication of heteroscedasticity in the model. 


\section{Hypothesis Testing}

Hypothesis 1: the use of smartphones has negative and significant impacts on family disharmony

Table 1

Analysis of the effects of smartphone use on family disharmony

\begin{tabular}{|c|c|c|c|c|}
\hline Model & $\begin{array}{l}\text { Unstandardized } \\
\text { Coefficient Beta }\end{array}$ & $\begin{array}{l}\text { Coeffcient } \\
\text { Std. Error }\end{array}$ & $\mathrm{t}$ & Sig. \\
\hline Constanta & - & & 13,930 & 0,000 \\
\hline $\begin{array}{l}\text { The use of } \\
\text { smartphone }\end{array}$ & $-0,134$ & 0,079 & $-1,701$ & 0,090 \\
\hline BKR & $-0,416$ & 0,067 & $-6,249$ & 0,000 \\
\hline \multicolumn{5}{|c|}{$\begin{array}{l}\text { Dependent variable = Family Disharmony } \\
\mathrm{R}=0,344 \\
\mathrm{R} \text { Square }\left(\mathrm{R}^{2}\right)=0,112 \\
\text { Se }=10,97655\end{array}$} \\
\hline
\end{tabular}

Source: Data Processing Results, 2019

Hypothesis 1 stated that the use of smart phones had a negative and significant effect on family disharmony. Table 1 showed that the calculated $t$ value was -1.701 and the significance value was 0.090 . That was, the use of a smart phone had a negative and not significant effect on family disharmony (H1 was rejected). In other words, family disharmony was not influenced by smartphone usage, but other factors outside the study. These results indicated an R-Square value of 0.112 or equal to $11.2 \%$. That was, the use of smart phones affects family disharmony $11.2 \%$ and the remaining $88.8 \%$ were influenced by other variables outside the study. Meanwhile, the magnitude of the path coefficient for other variables outside the study amounted to 0.9423 $(\sqrt{ } 1-0.112)$.

The results of this study contradicted the research (Rahma, 2015) which stated that the use of smart phones could have a negative effect, which makes adolescents experience dysfunction and the time of faceto-face interaction with others decreases. The results of this study were supported by (Odendaal et al., 2006) which stated that the use of technology does not have a negative impact on the communication of parents and adolescents without connecting other factors. However, the cause of family disharmony, namely the aspect of communication intensity in the family were: 1) attention during communication, 2) regularity, 3) breadth of message, and 4) depth of message, 5) depiction of self-image and the image of others, 6) psychological atmosphere, 7) physical environment, 8) tendencies were equally leading, and 9) mutual distrust (Hodijah, 2007).

In addition, seen from the respondents' answers from the thirteen indicators there were six highest mode values for the responses given by the PKK group in the statement item $5,7,8,9,11$ and 13 with a score of 4 . That was, the respondent could not be separated from smartphone usage. They used smartphones to video call conversations, receive and send messages, read news online, and listening to music. Even though the respondent could not be separated from the use of a smartphone and the duration of its use was not more than 3 hours each day, parents could still socialize with children so that the relationship remains harmonious. Some application content that was available on smartphones was not entirely used, such as games, social media, and video. Thus, it could be concluded that the use of smart phones among PKK mothers groups was limited to general communication needs and the intensity of use does not exceed 3 hours every day. 
Hypothesis 2: use of smartphones had a negative and significant impact on adolescent family development (BKR)

Table 2

Results of Analysis of the Effects of Smartphone Use on BKR

\begin{tabular}{|c|c|c|c|c|}
\hline Model & $\begin{array}{l}\text { Unstandardized } \\
\text { Coefficient Beta }\end{array}$ & $\begin{array}{l}\text { Coeffcient } \\
\text { Std. Error }\end{array}$ & & Sig. \\
\hline Constanta & - & & 30,528 & 0,000 \\
\hline $\begin{array}{l}\text { Smartphone } \\
\text { use }\end{array}$ & $-0,154$ & 0,068 & $-2,260$ & 0,025 \\
\hline $\begin{array}{l}\text { Dependent } \\
\mathrm{R}=0,154 \\
\mathrm{R} \text { Square }(\mathrm{I} \\
\mathrm{Se}=9,5572\end{array}$ & $\begin{array}{l}\text { variable }=\text { BKR } \\
\left.2^{2}\right)=0,017 \\
9\end{array}$ & & & \\
\hline
\end{tabular}

Source: Data Processing Results, 2019

Hypothesis 2 stated that the use of smart phones had a negative and significant effect on Adolescent Family Development (BKR). Table 2 showed the $t$ value obtained for $-2,260$ and a significance value of 0.025 . These results could be interpreted that the use of smartphones had a negative and significant effect on Adolescent Family Development (BKR). In other words, a smart phone did not affect the Adolescent Family Development (BKR). It could be concluded that hypothesis 1 was not rejected (H2 accepted). The results of this study also showed that the R-Square value of 0.024 or equal to $2.4 \%$. That was, the use of smartphones affects BKR 2.4\%, and the remaining $97.6 \%$ was influenced by other variables outside the study. Meanwhile, the magnitude of the path coefficient for other variables outside the study amounted to $0.8718(\sqrt{ } 1-0.024)$.

The data showed that the higher the use of a smartphone, the lower the Adolescent Family Development. In other words, communication act in the form of face to face has been diminishing. The diminished faceto-face communication was thought to have occurred because in reality, respondents' answers stated that adolescents felt parents did not want to hear and receive input from adolescents and did not always do two-way communication when discussing various things. This was evident from the answers adolescents do not agree on the questionnaire given. The results of this study were in line with research (Muflih et al., 2017) which revealed that the use of smart phones caused a dependency and impacts on the lack of social interaction, especially in the family sphere. However, the results of this study contradict (Yoga Arief, 2018) which stated that communication between parents and adolescents was more done through face to face compared to using a smartphone, even face to face communication was more ideal.

Communication is an essential thing in the family. Through communication, family members could express their needs, desires, and concerns for each other (Lestari et al., 2015). In this digital age, communication activities were also inseparable from technology. The use of smart phones was one product of the development of information and communication technology. The use of a smartphone as a means of communication had a negative impact on the communication of parents and adolescents if the intensity of its use was excessive. Excessive use could reduce interpersonal abilities (Odendaal et al., 2006).

Hypothesis 3: the use of smartphones had negative and significant impacts on family disharmony through adolescent family development (BKR)

Hypothesis 3 stated that the use of smart phoneshad a negative and significanteffecton family disharmony through the Adolescent Family Development (BKR). The table above showed that the $t$ value obtained was -2.260 on the indicator of smartphone use to the BKR with a significance value of 0.025 . While the $t$ value of -6.249 on the BKR indicator of family disharmony with a significance 
value of 0,000 . The results mean BKR was able to mediate the relationship between smartphone usage and family disharmony so that hypothesis 3 was accepted (H3 was accepted). The higher the use of smart phones accompanied by effective communication between parents and adolescents, the lower the family disharmony.

Considering the important role of parents, a management of Adolescent Family Development (BKR) was needed. The purpose of the BKR was to increase the knowledge of parents and adolescents so that awareness and responsibility of children and adolescents arise in order to improve family resilience through healthy, harmonious communication interactions in an atmosphere of happy and prosperous household life. It was important for parents to understand adolescence because adolescence was the future of every society. Adolescence was a phase of development between childhood and adulthood, lasting between the ages of 12-24 years (WHO, 2010). BKR activities were very strategic in striving for the realization of potential human resources through efforts to increase family knowledge and skills in caring for and fostering adolescent growth and development through the role of parents.

Because of these impacts, there was a need for guidance, direction and supervision from parents in order to avoid negative impacts that result in undesirable things.
Families were required to adapt and understand the development of adolescents in the era of technological progress. It was inevitable that this development affects the lives of every family member structurally or culturally. One form of government efforts to anticipate negative impacts was the Youth Family Development Program (BKR). BKR was the spearhead of the Planning Generation Program (GenRe). However, not all BKRs were running and active (Pyas \& Satlita, 2017).

BKR activities could run well if controlled using five appropriate indicators (Nugroho, 2011), Indicators that could be used to measure the effectiveness of these activities were 1) right policy, 2) right implementer, 3) right target, 4) right environment, and 5) right process. In fact, BKR was expected to be able to increase the knowledge and skills of parents and other family members in the care and development of adolescent growth and development in order to increase participation, guidance and independence in family planning for group members. BKR was a positive and beneficial activity to assist parents in fostering adolescents to become quality adolescents and creating family harmony.

Figure 1 showed the Sobel Test of this study. Sobel test was conducted to determine whether Adolescent Family Development could be used as an intervening variable or not.

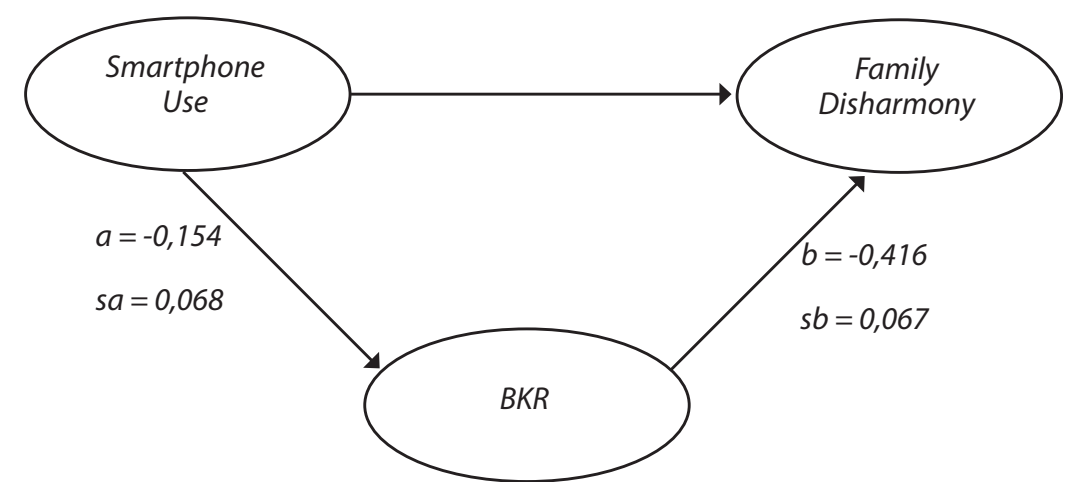

Figure 1. Sobel Test 
Based on the above figure, the following sobel test results were obtained:

Table 3

Sobel Test

\begin{tabular}{llll}
\hline & $\begin{array}{l}\text { Tets } \\
\text { Statistic }\end{array}$ & $\begin{array}{l}\text { Std } \\
\text { Error }\end{array}$ & p-Value \\
\hline $\begin{array}{l}\text { Sobel } \\
\text { Test }\end{array}$ & 2,12759486 & 0,030111 & 0,03337069 \\
\hline
\end{tabular}

$\alpha=-0,154$

$\mathrm{B}=-0,416$

Source: Data Processing Results, 2019

From the calculation of the sobel test it could be seen that the $t$ value was 2.127 and the $p$ value was 0.033 ( $p$-value $<0.05$ ). So, it could be concluded that the BKR variable could be used as an intervening variable relationship between the variables of smartphone usage and family disharmony.

Table 4

Path coefficient (Beta) Direct and Indirect Relationship of Research Variables

\begin{tabular}{|c|c|c|c|c|}
\hline \multirow{2}{*}{$\begin{array}{l}\text { Influence } \\
\text { between } \\
\text { Variables }\end{array}$} & \multirow{2}{*}{$\begin{array}{l}\text { Path } \\
\text { coefficient } \\
\text { (Beta) }\end{array}$} & \multicolumn{3}{|c|}{ Causal Influence } \\
\hline & & Direct & Indirect & $\begin{array}{l}\text { Joint } \\
\text { Influence }\end{array}$ \\
\hline$X \rightarrow Y$ & $-0,134$ & $-0,134$ & $\begin{array}{l}=-0,154 x- \\
0,416= \\
0,064\end{array}$ & - \\
\hline$X \rightarrow Z$ & $-0,154$ & $-0,154$ & & \\
\hline $\mathrm{Z} \rightarrow \mathrm{Y}$ & $-0,416$ & $-0,416$ & & \\
\hline
\end{tabular}

Source: Data Processing Results, 2019

Based on the results of the study, it could be concluded that the path coefficient of the use of smart phones to family disharmony was -0.134 , the path coefficient of the use of smart phones to the Adolescent Family Development Program (BKR) of -0.154, and the path coefficient of Youth Family Development (BKR) to family disharmony of $-0,416$. The path coefficient value was -0.134 . That was, the use of smart phones to family disharmony was a direct relationship (indirect). Meanwhile, the indirect relationship which was the path coefficient value of the use of smart phones to family disharmony through the Adolescent Family Development (BKR) is 0, 064. Therefore, if the path coefficient value was included in the equation then the following data were obtained:

$\mathrm{BKR}=30,528+(-0,154)$ Smart Phone Users + 0,068

Family Disharmony $=30,528+(-0,154)$ Smartphone users $+(-0,416)$ BKR $+(-0,416)$ BKR + 30,5281

Equation (1) could be interpreted that when the use of smartphones increases, it will reduce the Adolescent Family Development Program (BKR) 0.154. The equation (2) could be interpreted that when the use of smart phones and BKR increases, the family disharmony will decrease by 0.134 and 0.416 .

\section{Conclusion}

The use of a smart phone had a negative and not significant effect on family disharmony. That was, the higher use of smart phones does not affect family disharmony. Effective communication between family members needs to be maintained to maintain harmonious family conditions. Communication could be done by direct or indirect communication. Even though every family member used a smartphone in daily life, if it was used wisely, it will not result in family disharmony. The use of smartphones had a negative and significant effect on the Adolescent Family Development program. That was, the higher the use of smart phones, the lower the direct communication made by parents and children in a family.

Directcommunication wasrecommended when families gather at home. Thus, each family member was not only busy with their 
respective smart phones which could reduce the quality of direct communication between family members. It could be said that the higher the use of smartphones, the lower the family disharmony through the Adolescent Family Development. In other words, the direct communication within the family function of the BKR continues to be applied in a family to strengthen the relationship patterns of children and parents so as to reduce family disharmony. BKR could help maximize 8 family functions, namely the function of religion, social culture, love and affection, protection, reproduction, socialization and education, economics, and environmental functions. The Adolescent Family Development Program (BKR) was indeed needed as a means of monitoring and directing adolescents to be wiser in using smartphones. The program could also help parents direct adolescents who were mostly in the search for identity so that teens do not fall into actions that could violate the norms and values that apply in society.

Future studies could add other variables besides the use of smartphones to find out the cause of family disharmony. Data collection methods could add qualitative studies in order to obtain more in-depth data about the cause of family disharmony. BKR program was needed by the community, especially to improve family harmony to reduce the level of deviation in adolescent behavior such as infectious diseases such as HIV / AIDS, drugs, premarital sexual behaviour and others.

The BKR program should be emphasized more on the socialization of eight family functions so that parents will understand more about the role of parents in the family. The effectiveness of meetings in the BKR group was needed to monitor parental care towards adolescents to anticipate deviations of adolescent behavior to create quality adolescents. Regular outreach about the importance of reproductive health to parents and adolescents should be done to minimize the deviation of adolescent behavior.

\section{Declaration of Ownership}

This article is our original work.

\section{Conflict of Interest}

There is no conflict of interest to declare in this article.

\section{Ethical Clearance}

This study was approved by the institution.

\section{References}

Direktorat Jendral Pencegahan dan Pengendalian Penyakit. (2018). Laporan perkembangan HIV-AIDS \& infeksi menular seksual (IMS). Kementerian Kesehatan Republik Indonesia.

Kusumaryani, M. (2017). Brief notes: Prioritaskan kesehatan reproduksi remaja untukmenikmatibonus demografi. Lembaga Demografi FEB UI.

Lestari, I., Riana, A. W., \& Taftazani, B. M. (2015). Pengaruh gadget pada interaksi sosial dalam keluarga. Prosiding Penelitian dan Pengabdian Kepada Masyarakat, 2(2), 204-209. https://doi.org/10.24198/jppm. v2i2.13280

Muflih, Hamzah, H., \& Puniawan, W. A. (2017). Penggunaan smartphone dan interaksi sosial pada remaja di SMA Negeri 1 Kalasan, Sleman Yogyakarta. Idea Nursing Journal, 7(1), 12-18.

Nugroho, R. (2011). Public policy: Dinamika kebijakan-analisis kebijakan-manajemen kebijakan. Elex Media Komputindo.

Odendaal, W., Malcolm, C., Savahl, S., \& September, R. (2006). Adolescents, their parents, and information and communication technologies: Exploring adolescents' perceptions on how 
these technologies present in parentadolescent relationships. Indo-Pacific Journal of Phenomenology, 6(1), 1-8. https:// doi.org/10.1080/20797222.2006.11433916

Permana, K. S. (2019). Ketika pengguna internet dan telepon pintar terus meningkat, android dominasi pasar indonesia dan dunia. Tribunjabar.id.(https://jabar.tribunnews. com), accessed in 10 May 2020.

Pyas, D. W., \& Satlita, L. (2017). Efektivitas pelaksanaan program generasiberencana dalam meningkatkan kesehatan reproduksi remaja di kota Yogyakarta. Natapraja, 5(1), 97-106. https://doi. org/10.21831/jnp.v5i1.18756

Rahmah, A. (2015). Pengaruh penggunaan smartphone terhadap aktivitas kehidupan siswa. Jurnal Online Mahasiswa FISIP, 2(2), 1-12.

Resti, I. (2015). Penggunaan smartphone di kalangan mahasiswa fakultas ilmu sosial dan ilmu politik Universitas Riau. Jurnal
Online Mahasiswa FISIP, 2(1), 1-15.

WHO. (2010). World heath statistics: 2010. World Heath Organization.

Widiartanto, Y. H. (2016). Pengguna internet di Indonesia capai 132 Juta. ( h t t p s:// tekno.kompas.com/ read/2016/10/24/15064727/2016. pengguna.internet.di.indonesia. capai.132.juta), accessed in 15 May 2020.

Widiastuti, N., \& Elshap, D. S. (2015). Pola asuh orang tua sebagai upaya menumbuhkan sikap tanggung jawab pada anak dalam menggunakan teknologi komunikasi. Jurnal Ilmiah P2M STKIP Siliwangi, 2(2), 148-159. https:// doi.org/10.22460/p2m.v2i2p148-159.174

Wojowasito, \& Poerwadarminta. (1985). Kamus lengkap bahasa Indonesia. Ichtiar Baru. 
Puji Nurhayati, Pratama Dharmika Nugraha, Heidy Paramitha Devi, Andri Wahyu Utomo 